\title{
Offending Pictures. What Makes Images Powerful
}

Christiane Kruse

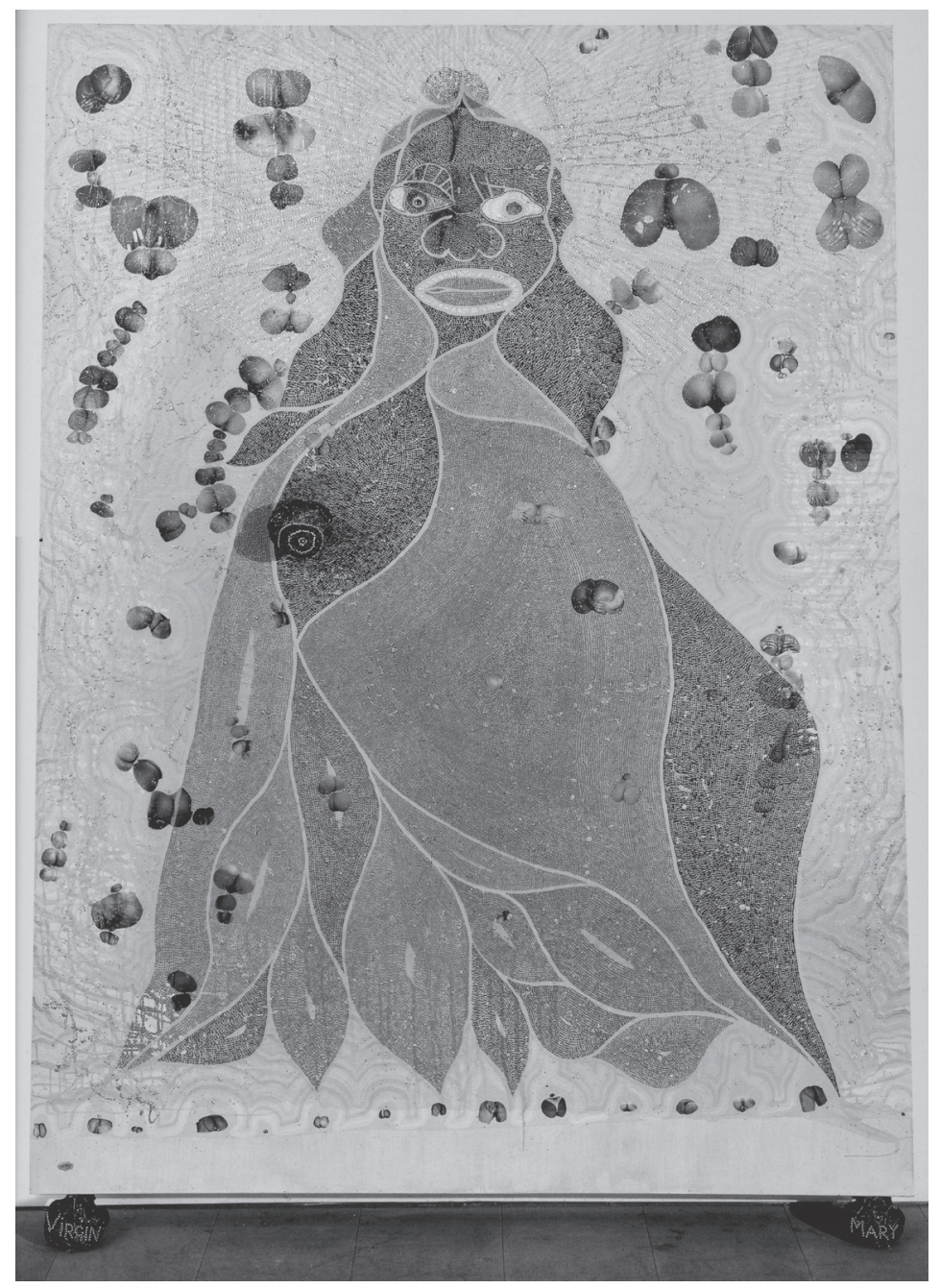

[FIG. 1]

Chris Ofili: The Holy Virgin Mary, private collection, 1996 
(Fig. I) The painting depicts in linear, flat terms a woman of color wearing a blue garment and surrounded by leaf ornaments against a gold background. The schematic drawing of the woman's face enlarges and bloats the facial features of an African ethnicity. At the height of the figure's breast, a small cylindrical element ending in three concentric circles breaks through the surface. The golden ground with the starburst surrounding her face is reminiscent of icons or medieval paintings of saints. Small flesh-colored, bulbous visual components are scattered over the surface in irregular fashion. Some of them are shaped like flowers, while others recall beetles and caterpillars. A closer look reveals that the forms are in fact photographs of female genitals glued onto the painting. The work is propped on two clumps; on the left clump the word »Holy« can be read, on the right the word »Virgin.«

\section{Offending Images}

In his book with the provocative title What Do Pictures Want?, William Thomas Mitchell dedicates a chapter to $»$ the nature of offending images. $\ll^{\mathrm{I}}$ Mitchell lists an entire set of criteria that suffice for a picture to qualify as offensive. Offensiveness is often effected by the specific objects that materialize an image, while representations of the sacred are especially suited to the purpose. ${ }^{2}$ Mitchell demonstrates that pictures have the power to provoke and even insult their viewers. Not infrequently, this provocation ends in a picture's destruction. The reason for this, as Mitchell sees it, is that pictures are treated as pseudo-persons. A magical power is ascribed to them; they embody a pseudo-life or aliveness. According to Mitchell, 
the magical power that pictures seem to have doesn't fit in with our enlightened world, but has its origins in superstition, in religious communities, and in "primitive cultures.«For this reason, pictorial magic belongs to an earlier stage of civilization. In his study, Mitchell seeks to demonstrate that seemingly archaic, superstitious notions that were long considered overcome survive in visual artifacts and induce viewers to treat pictures as living beings. People who remove pictures, who s punish them through defacement, or who seek to destroy them in an act of violence are acting within this "primitive« stage of civilization.

According to Mitchell, offending pictures are often located on the »frontlines of social and political conflict. « From the Byzantine iconoclasm of the $9^{\text {th }}$ century to the destruction of the Twin Towers or, more recently in 2015 , the destruction of a temple in Palmyra at the hands of IS militants, politically or religiously motivated iconoclastic acts have always taken place and always will. Moreover, art has often unwittingly or, in the avant-garde movements of the $20^{\text {th }}$ century, deliberately provoked offense with shocking pictures. Mitchell lists twelve examples from art and visual history ranging from the ancient portrait of the Emperor Nero to Damien Hirst's This Little Piggy Went to Market, and he distills from them four »obvious points « of the offending picture that are primarily intended to support his thesis of the living image. ${ }^{3}$ First, the offending quality of images is contingent on complex social contexts that, when changed, can rehabilitate the incriminated image. Second, images can be considered offensive for very different »offenses: these can be political, religious, or moral in nature. Third, offensive images can even be prohibited by law and can lead to court cases. Fourth, the degree of iconoclasm varies from injury to destruction, or can simply mean the concealment of an image. 


\section{Pre-existing Attitude in the Viewer}

To my mind, Mitchell's thesis that the offending nature of pictures derives from a primitive belief in their aliveness seems too one-sided, not consistently thought through to its conclusion, inasmuch as he remains uninterested in the complementary question that draws closer to the pictures and our dealings with them: why does a picture offend one viewer, to the point that he or she wishes to destroy it, while another viewer remains entirely indifferent to it? Let's take the example of the painting that I described above: The Holy Virgin Mary by the British artist Chris Ofili (Fig. I). Mitchell presents the scandal the painting caused in the exhibition Sensation at the Brooklyn Museum (1997) as proof of his living image thesis. ${ }^{4}$ A prominent and influential viewer of pictures, the New York mayor Rudolph Giuliani, called it »sick stuff « and ordered the museum's funding to be cut. Dennis Heiner, a retired teacher, took advantage of an unguarded moment in the Brooklyn Museum to cover the painting in white latex paint in an effort to eliminate the image he found scandalous. (Fig. 2). ${ }^{5}$ Museum staff, arguing from the perspective of art's autonomy, were horrified by the iconoclastic act and hastened to restore the painting to its original condition. The exhibition had opened in the London Royal Academy, traveled to Berlin (Hamburger Bahnhof, Museum für Gegenwart), and was subsequently shown at the Brooklyn Museum in New York - and it was only there that it caused a scandal. The catalyst, according to Mitchell, was the artistic material of elephant dung, considered inappropriate for the subject matter. The cylindrical naked »breast« of The Holy Virgin Mary is made from a lump of elephant dung, with a nipple stuck on top (Fig. 3). The entire painting rests on two more clumps of the same material 
with the inscriptions described above — »Holy« on the left and »Virgin« on the right - engraved with a needle. According to the Manchester-born artist of Nigerian heritage, elephant dung is a fertility symbol in African cultures. Mitchell might not have observed the painting closely enough, because he fails to mention the photographs of female genitals collaged in the form of beetles and butterflies scattered over the entire surface, »flying around « the Madonna (Fig. 4).

According to Mitchell, for a picture to be offensive, it is essential that the artist implement the visual material with provocative intent. ${ }^{6}$ Also essential in this respect is the pre-existing attitude of the viewer, who, like Giuliani - the Catholic son of Italian immigrants to New York ${ }^{7}$ — views pictures either as an art expert or from some other political, religious, or otherwise culturally influenced perspective. This is because the picture, with its visual subject, $>$ behaves $<$ in a passive manner: it can't anticipate the perspective from which a viewer will regard it. What's far more interesting is the dialectic »nature « of a picture, which can be both alive and dead, offensive, attractive, or uninteresting. From an art-historical point of view, it is likely that an aberration from the iconographic tradition is the first thing a viewer will notice: the Christ child that made Mary the Holy Virgin could be missed in the painting. Furthermore, the art historian is bound to respect the autonomy of art and to ascribe both the incriminating material and the butterfly-shaped genitals to the expansion of artistic materials and the provocations that appeared in $20^{\text {th }}$ century art. For the expert in contemporary art, the wide range of discourses that the painting evokes is interesting and comes as no surprise. When these discourses are analyzed more closely, the conclusion is drawn that judging pictures in today's pluralistic societies is not an indication of their metaphoric »aliveness, « but rather a symptom of serious 


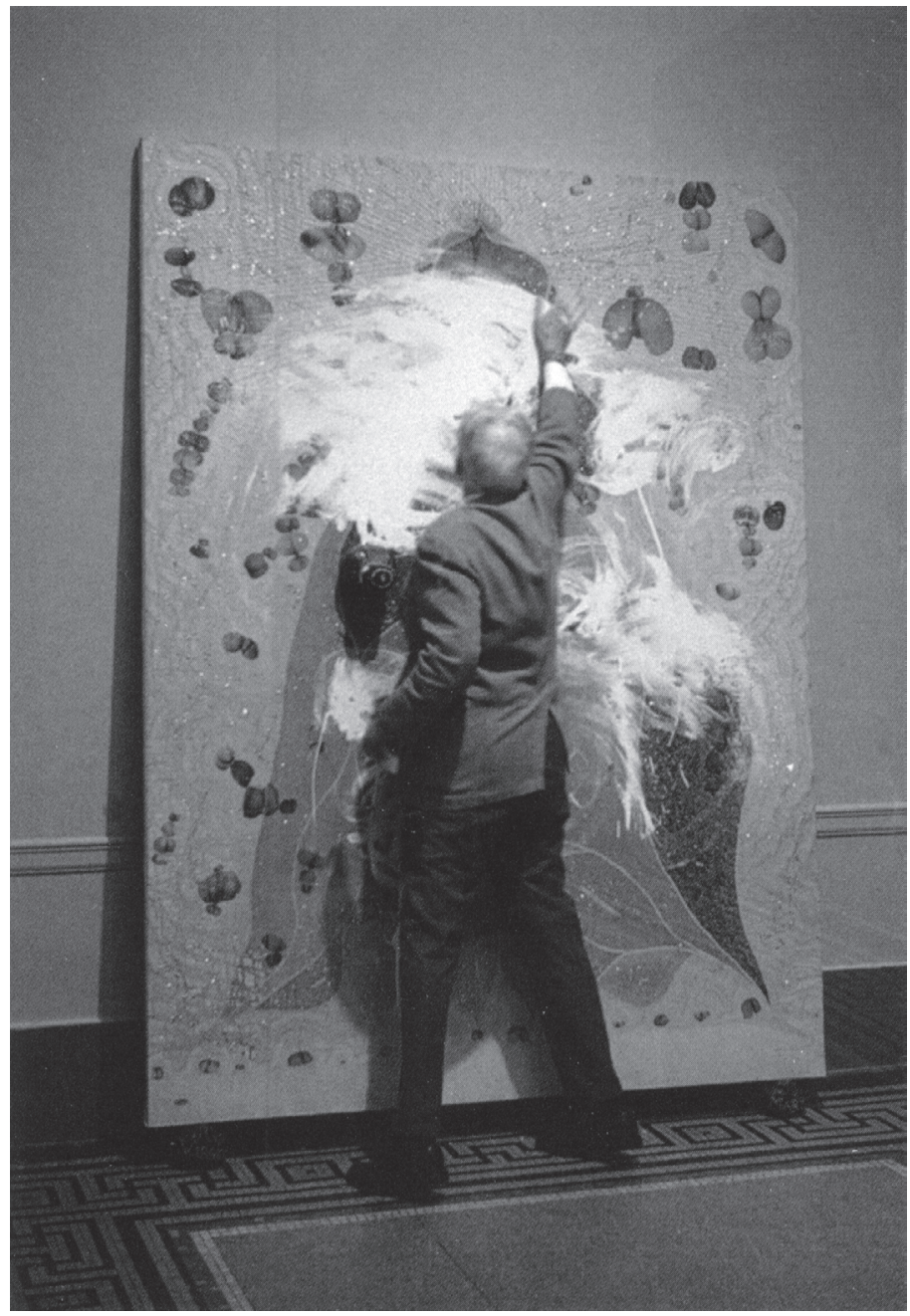

[FIG. 2]

Dennis Heiner smearing white paint over Chris Ofili's work

during the exhibition at the Brooklyn Museum of Art, New York,

December 1999 

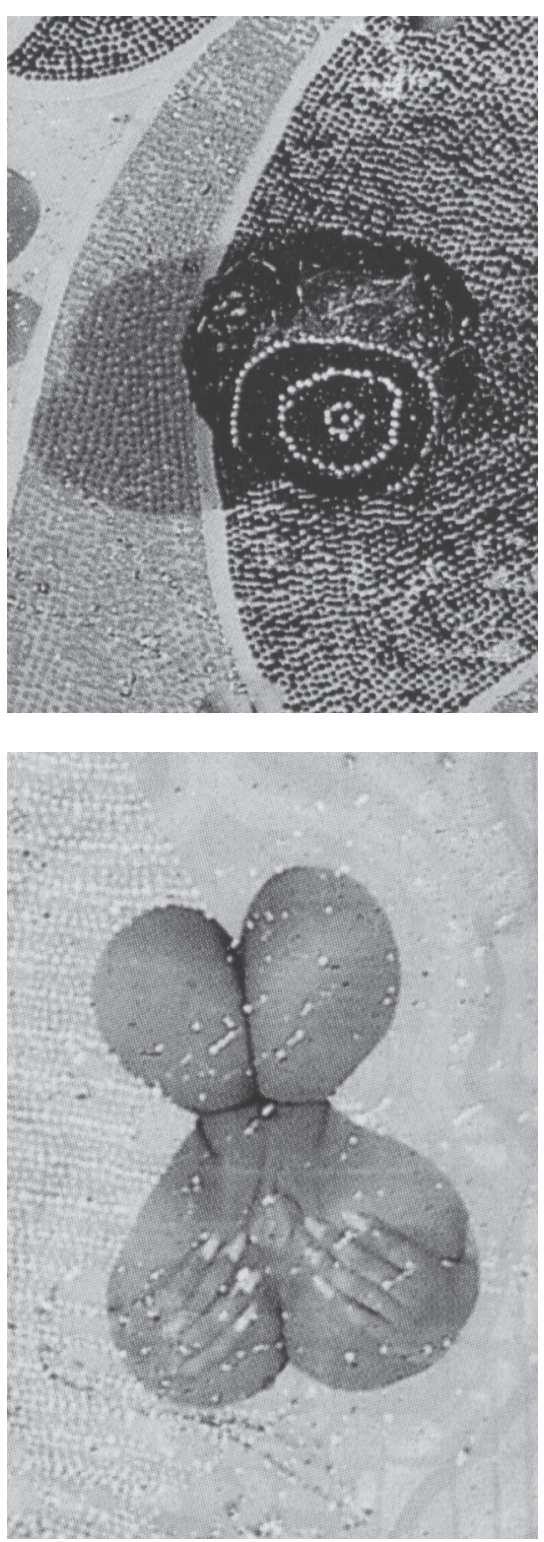

[FIG. 3]

Chris Ofili: The Holy Virgin Mary, the virgin's breast (detail Fig. I)

[FIG. 4]

Chris Ofili: The Holy Virgin Mary, flying vaginas (detail Fig. I) 
ideological differences, whether these be religiously, politically, gender-thematically, artistically, or otherwise motivated. These differences are acted out in front of a lifeless object that distinguishes itself from other objects by virtue of the fact that the societies' members have given it a function as symbol. ${ }^{8}$ As material forms, pictures embody and communicate the diverse political, religious, and other cultural values (i.e., art) that individual members of society, groups within a society, or the society as a whole identify with. ${ }^{9}$ This is what Mitchell is saying when he writes that "pictures, including world pictures, have been always with us, and there is no getting beyond pictures, much less word pictures, to a more authentic relationship with Being, with the Real, or the World. « ${ }^{10}$ Thus, a material picture body is required in order to form a picture of the world in the first place. $^{\text {II }}$

For this reason, offensiveness and attraction are accidental qualities of a picture and reside in the eye of the beholder, who turns a lifeless, mute object into a symbol of cultural value he or she can identify with. If a picture disrupts these values in any way or to any degree, it can cause shock, and if it confirms these values, joy. Mitchell's study does not address the interesting fact that the same picture can leave another viewer entirely indifferent, and that he or she can fail to perceive the affirmation or breach of values of the mute, lifeless object that makes no personal impression, and instead pass it by without taking any notice.

My second example shows the photograph of a slender man with a dark, closely trimmed beard and long, well-groomed hair wearing a close-fitting, elaborately embroidered golden dress (Fig. 5). The man is holding his arms out at his sides. His heavily made-up eyes and long hair emphasize his feminine features. He is holding a microphone in his right hand. The youthful figure, 


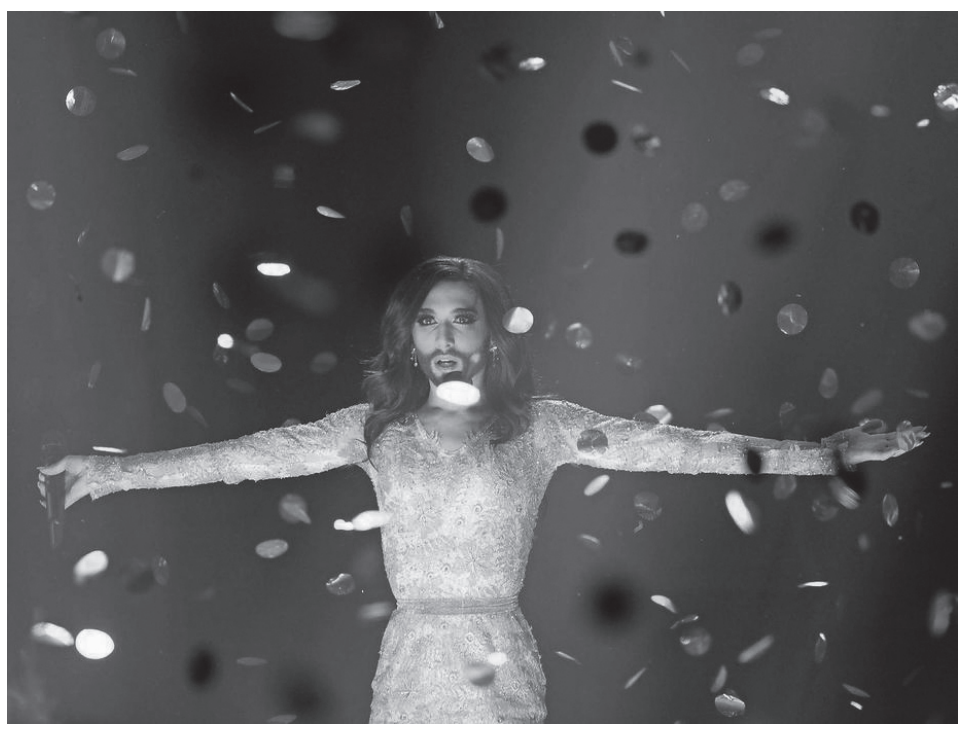

[FIG. 5]

Conchita Wurst's appearance at the ESC, 2014

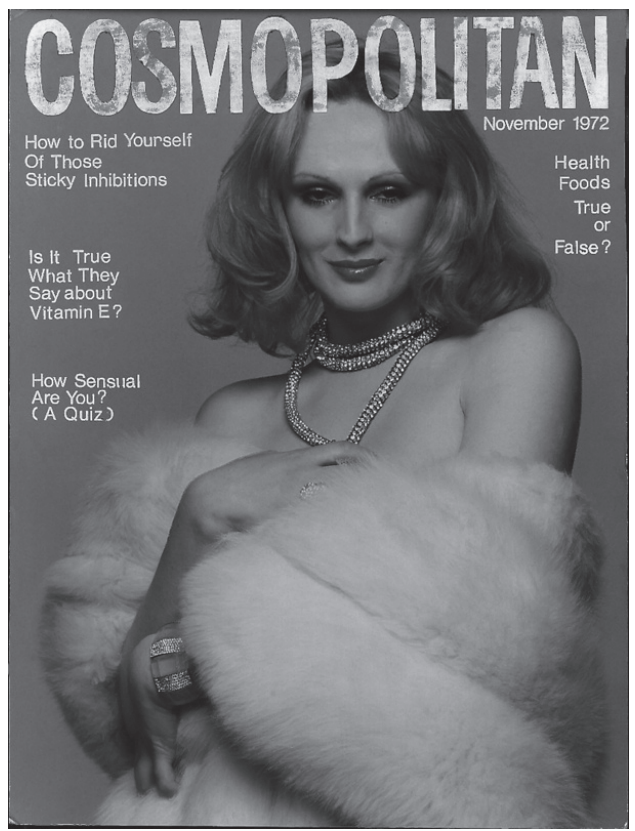

[FIG. 6]

Candy Darling, Cosmopolitan, Nov. 1972 (photo by Francesco Scavullo) 
the face, the frontal pose, and the golden dress make a festive impression. Thin golden discs as large as thalers are falling around him. The man is reminiscent of Jesus, and his pose resembles late medieval depictions of the Crucifixion.

\section{Iconoclasb}

In his essay on the Karlsruhe exhibition Iconoclasb (2002), Bruno Latour listed the criteria at play when a viewer takes offense at a picture and formulated a typology of the iconoclast. ${ }^{\mathrm{I2}} \mathrm{Here}$, too, the indifferent viewer of pictures is missing. Latour defines the idea of the »iconoclash as what happens when there is uncertainty about the exact role of the hand at work in the production of a mediator. Is it a hand with a hammer ready to expose, to denounce, to debunk, to show up, to disappoint, to disenchant $[\ldots]$ ? Or is it, on the contrary, a cautious and careful hand, palm turned as if to catch, to elicit, to educe, to welcome, to generate, to entertain, to collect truth and sanctity? « ${ }^{13}$ In this sense, the iconoclash is a tension, an ambivalence embedded in the picture that leads one viewer to see the painting as sacred and the other as sacrilege. In this vein, the destruction of a picture is a war by proxy: the real target is the one who destroys another person's »false idols« in order to erect his own, which are then to be regarded as »true. « ${ }^{14}$ The acting agency is also dependent on the cultural identity, education, and outlook of the picture producer, who has his own reasons for his production. Art, as I sought to show with my first example, Chris Ofili’s The Holy Virgin Mary (Fig. I), is one of many examples of Latour's iconoclash: an experiment with the viewer, who is called upon to ponder, in this case, the connections between sacredness 
and art, Madonna and elephant dung, a light-skinned Mary and a Mary of African heritage, etc. The painting, on view in a museum, demonstrates another method of enlightened thinking concerning the way paintings like The Holy Virgin Mary can be approached: the predetermined art context highlights the historically contested and legally secured freedom of the artist, the autonomy of art since the modern era. ${ }^{15}$ With this freedom, the work of art offers scope for reflection to all viewers interested in considering a possible connection between a Mary with African heritage, female genitals, and elephant dung and who for this reason find the painting fascinating — or are outraged by it. The destruction of art is subject to prosecution in the Western world. In times of globalization, the museum - a place of living democracy — becomes a symbolic space for tolerance in pluralistic societies. The arguments for or against a picture should be carried out with words and not, as in New York, punished with political sanctions.

But what about the second example (Fig.5)? The photograph shows Thomas Neuwirth, alias Conchita Wurst, the winner of the Eurovision Song Contest (ESC) in May 20I4. Together with other photographs, it was widely disseminated through various mass media and soon unleashed an iconoclash. Conchita's widely covered Copenhagen performance was characterized as a »cross between martyr and savior. ${ }^{16}$ Depending on people's pre-existing socio-political or religious attitudes, Conchita Wurst inspired either enthusiasm or hatred among astonished viewers. People immediately recognized the allusion to a Christ icon in the fictional persona and complained that nothing about Conchita Wurst's physical appearance fit together: the dress, a mixture of ball gown and penitential robe, didn't quite suit the performer's androgynous figure; the eyes, gazing heavenward through false eyelashes, didn't match the dark beard, which in turn clashed 
with the dress and a Latino beauty's long hair. The visual impression that Conchita made on her critics clearly oscillated between a figure of salvation and a devil. »Euro-homos burn in hell, « cried the Russian right-wing nationalist Vladimir Zhirinovsky.7 On the other hand, Vienna’s Archbishop, Cardinal Christoph Schönborn, was pleased with the performer's success and attributed it to »God's multi-colored garden, « in which there are also people who feel they are members of the opposite sex and »of course deserve our complete respect. ${ }^{18}{ }^{18}$ Tom Neuwirth's TV appearance as Conchita Wurst quickly transformed the performer into an icon. The image he presented as a bearded, long-haired lady in a ball gown sparked a widely covered public debate that strongly polemicized homosexuality and tranvestitism and legitimized each individual's freedom to assume a gender identity apart from the heterosexual mainstream. This photograph also shows how pictures, as symbols of cultural (and in this context, religious) values, respond to complex social contexts and not only transport our »relationship with Being, with the Real, or the World« (Mitchell, see above), but construct them in the first place.

Anyone who hadn't previously formed an opinion on transgenderism could, after seeing this picture and the surging flood of imagery it unleashed, feel called upon to take part in the debate - or simply to marvel at how a pop star dressed as a bearded woman could agitate high-ranking politicians and induce a high-ranking Catholic official to utter words of tolerance. What makes the phenomenon of the offensive picture so interesting is the »sensational form « that has resulted from different viewer standpoints and contexts produced discourses and iconoclashes, and generated ambivalence. ${ }^{19}$ Three types of picture viewers can be identified here, each of which behaves in a certain way toward the picture: 
the picture lover, the picture destroyer, and the viewer who is indifferent to the picture. The arguments a viewer might have for or against a picture, or not at all, promise more than just information on how pictures are dealt with. The opinion an individual person expresses about a picture reveals much about his or her salient ideological sensibilities. In most cases, the offensive picture is a cause for negative emotions, which the picture haters would like to try to justify by arguing with hard facts. On the other hand, the picture lovers will express positive emotions about the picture: the picture is able to inspire them, capture them, and fill them with joy or astonishment. It's not always clear what reasons lie behind this affection. On the other hand, the indifferent viewers feel nothing in response to the picture; either they will overlook it completely or feel neither pulled toward nor repulsed by the picture. It means nothing to them. Each of us brings different degrees of attention to bear in response to the mass of pictures in today's visual culture: most of them flit by in any case; they fail to interest us for a variety of reasons - only very few pictures have a strong enough effect to make us look at them. Let's try to understand how this happens.

\section{Powerful Pictures}

A picture requires a certain power for it to have an offending or appealing effect. What, then, makes pictures so powerful? Offense and appeal are, as we have seen, effects that are part of the picture, but do not exist objectively to the extent that they reach every viewer: thus a picture can seem both strong and weak. My inquiry into the power of pictures is relevant particularly in light of 
the sheer quantity of them circulating globally. Which pictures are seen amid this seemingly endless mass, and which ones attract attention? What are the visual attributes, material makeup, aesthetic quality, what content and cultural contexts do pictures have that - to make use of a current metaphor - emerge from this flood of imagery, that resist drowning in the whirlpool and can either rescue themselves on the banks of visibility or be pulled out of the current to be viewed, interpreted, and become, in whatever way, culturally effective in the broadest sense of the word?

And, regarding art in the age of mass-media imagery: what "power« do pictures from an art context possess? In many cultures, pictures have been collected for centuries and have been preserved from destruction by being stored or exhibited in museums. What role do the pictorial traditions of various cultures' art histories play in the flood of images? Are pictures that arise and are viewed today in an art context more powerful than pictures that exist in a non-art context?

In the following, the word »powerful« refers solely to the degree of effect a picture has in the various different debates; in this sense, even innocuous pictures can be powerful. In a general sense, powerful pictures attract attention: they are disseminated throughout the media, people talk about them, and they are quoted in other pictures or different media. Their effect can fade quickly, or it can remain visible, linger, and increase in power. Pictures, whether from the art context or not, that cause offense or appeal belong to the category of those powerful pictures that emerge from the flood of imagery. There are, however, very different reasons behind their respective power. Offensive and appealing pictures are fished out of the colorful flood of imagery and equipped with arguments that support the offense or attraction. In this way, they can also reach 
those who would have passed them by without noticing them and who now stop to wonder why this picture in particular is able to offend or attract. As we've seen, Chris Ofili's painting is one of these cases. On the other hand, pictures that are produced in an art context are fished out of the flood because they require arguments to justify their preservation, for instance in a museum. This also applies to Ofili's Holy Virgin Mary, which was shown in three internationally renowned art museums as Young British Art. Thus, Ofili's Virgin is a powerful picture for two reasons, with the scandal unleashed in the Brooklyn Museum increasing the painting's power.

»Conchita, « as her inventor's statement reads, »is a fictional figure, Tom Neuwirth's alter ego. And what we fictional figures make is art. ${ }^{20}$ The roleplaying of a man glamorously dressed as a bearded woman in the context of massmedia entertainment culture has its origins in the drag queens of Warholian Pop Art provenance (Fig. 6). Whether or not she »makes it« into the museum to prove the art status she lays claim to remains to be seen. In the year 20I4, Conchita Wurst represented an updated version of the pop transvestite; and as a fictional persona, Neuwirth has given her a clear political statement, namely that of »fighting for people who are discriminated against on a daily basis. « ${ }^{21}$ Her image embodies a collision of two different moral values: the allusion to Jesus with his purity, innocence, and holiness is paired with a manifestation of bearded femininity, putting transgenderism and homosexuality on display, which are politically and morally shunned in many societies. This contradiction lent Neuwirth's Conchita Wurst persona a visual power and a resulting omnipresent visibility that stood out as an iconoclash. The image was hotly debated for a short time and had a powerful effect in the sense described above. 


\section{Visibility}

Pictures with a strong offending/attracting effect are visible — and they can also come to the attention of those who don't really want to become involved with these pictures, but only notice them after other viewers who have found these pictures offensive or attractive have brought them into discussion. And we already have named two criteria of powerful pictures that are defined in formal aesthetic and phenomenological terms: visibility and effectiveness.

»Visibility is the possibility to be seen, "writes Lambert Wiesing in his study Die Sichtbarkeit des Bildes [The visibility of the image]. Yet how is the visibility of an image different from other visibilities? Following the art theoretician Konrad Fiedler (184I - I895), Wiesing defines the visibility of an image as a »special form sui generis, $\ll^{22}$ in that the visibility of a picture's surface is not identical to the visibility of the object present: »Each picture has to raise its surface to an autonomous phenomenon, which means to establish a difference between the picture's surface and the material of the picture. $\ll^{23} \mathrm{Each}$ picture that depicts an object transforms it into visibility and in doing so accepts that the object can no longer be touched, smelled, heard, or used. The picture »disempowers reality; « it negates and destroys reality in order to set up a »visual effect sui generis« in its place. In phenomenological terms, the pure visibility of the picture is defined as an autonomous form of being - and not as a form of appearance contingent on being, as it is for Plato. Thus, a picture constitutes an autonomous reality through the secession and absolutization of visibility. From this, Fiedler developed the notion of the "pictorial creation of the world, « according to which the picture generates 
its own world. The pure visibility of the picture depends on a material carrier. Visibility is produced by shaping the material in which the image is expressed. Paradoxically, producing the visibility of pictures requires rendering invisible the very material necessary for the image to become visible - it's only then that the world of images can arise, images characterized by pure visibility.

This can take us further regarding the problem of the offense/attraction of pictures. In the case of Ofili's The Holy Virgin Mary, for the viewer who, like Rudolph Giuliani, encounters the painting, the traditional pictorial form of the Catholic Madonna as it was developed and consolidated in Western art history collides with the pictorial form developed by Ofili, which deviates from this traditional visibility. ${ }^{24}$ Added to this is the material used, which is unusual in the tradition of the Madonna paintings and which particularly disturbed Giuliani, as did the flying vaginas on the traditional gold ground. Anyone who compares Ofili's The Holy Virgin Mary with the reality of church- and art-sanctioned cult images of saints can feel as though these have lost their power, because Ofili's painting creates its own world, one that deviates from the usual appearance of the picture of the saint. Thus, The Holy Virgin Mary has the potential to exert an effect on devout Catholics in New York or in other places around the world as an attack on matters of religious faith as they are traditionally depicted in paintings of saints. But it is also just as possible to interpret Ofili's Madonna as an artist's call to deconstruct the traditional Madonna canon with a dark-skinned African version. This new version can be regarded as a picture that visualizes the Catholic doctrine of the Immaculate Conception by adding little photographs of flying vaginas to symbolize fertility. That is, a dark-skinned Holy Virgin Mary 
evokes arguments of post-colonial critique and non-traditional forms of showing virginity. ${ }^{25}$

Wiesing is further concerned with the question of »what a formal understanding of pictures considers to be artistic claims to truth. $\ll^{26}$ Let us follow his line of argument less in terms of art and truth, and more in terms of its potency, which is important for the criterion of a picture's offensive/attractive power. For this reason, let us replace Wiesing's term »art« with the more general term "picture (cf. footnote $\mathrm{I}$ ) in the following statement: »The picture [art] appears as an attack on the state of the viewer in that he or she has to be altered to see the world as it is represented. ${ }^{27} \mathrm{~W}$ iesing is concerned with a »rhetorical-pragmatic dimension « of the picture [of art], with the ways of seeing that the picture communicates: it induces »the beholder « to see the world with a changed perspective that is as closely related as possible to the change intended by the picture and its maker. »One could describe the way a world analysis functions with the phrase struth of the picture [of art], in other words, the picture's [artwork's] ability to represent and to interpret reality in a way that can also apply to others. $\ll^{28}$ This statement seems to apply to our two examples (Fig. I and 5). In the eyes of the viewer who is either offended or attracted by them, they each have the ability to create a world of their own that can cause the viewer to see the world in the way the picture dictates: in the case of Ofili's The Holy Virgin Mary, a Catholic Madonna, and in the case of Conchita Wurst, a Christ figure. This applies to the picture's ability to generate a new and different world through visibility; but how does the powerful effect of the picture come about? 


\section{Phenomena of Attention}

Bernhard Waldenfels addressed this in his book Sinne und Künste im Wechselspiel. Modi ästhetischer Erfabrung [The interplay of the senses and the arts. Modes of aesthetic experience]. Before he lists the criteria for a picture's potency that are helpful in understanding powerful pictures, he more generally examines experiences of the surprising and new. These, according to Waldenfels, arise not from an act intentionally directed at a certain object, but rather result from an »event in which something becomes visible.«Becoming attentive, however, is neither a subjective nor an objective process, but rather a »dual event:« »Something comes to my attention; I take notice. ${ }^{29}$ Waldenfels defines attentiveness as an initial experience, a primal phenomenon. Attracting attention (experience or affection $=$ pathos) bears features of the adverse, undesired, and injuring, and it stands out. As events, attracting attention (pathos) and paying attention (response) cannot be separated from one another. In this sense, offense is something that stands out negatively, while attraction is a positive stimulus. Hence, the effects of the offense/attraction are preceded by a cause: a surprise, an astonishment, a fright. "What we notice and what surprises us always comes too soon, while our response always comes too late. $\ll^{3^{\circ}}$ What matters here is the suddenness of this experience, a shift in time and space that splits the present, that points to an impossible coincidence in which the power of effect unfolds and emotions are unleashed.

In this regard, what is offensive/attractive employs a power that we cannot fend off, because the reasons behind its effect are not consciously understood at first. The rational mind does not grasp the reason behind the offense/ attraction, which exerts its effects on the emotions first and activates either 
resistance or attraction. Offense/attraction is experienced as an effect on the body and brings about a physical resistance or feeling of being attracted. In the initial experience of taking notice, the event that is evaluated in retrospect as offensive/attractive exerts its effect as an unconscious force that defies control. The offensive/attractive attribute disturbs the flow of habit and, in extreme cases of negative emotion, can be traumatizing or shocking.

Waldenfels distinguishes between two forms of attention: a primary, innovative, and creative form and a secondary one that proceeds in a repetitive and reproductive manner. An aspect of the second form is that »the events of attracting attention solidify into repeatable qualities, while the events of taking notice turn into bodily habit. ${ }^{31}$ In this way, it leads to what I termed above a »pre-existing attitude, «or, as Waldenfels formulates it, »to the formation of favored worlds of attention that mirror collective and individual interests. $\ll^{32}$ Strong forms of pathos are evidenced in the aberration from the habitual or traditional that transgresses the framework of existing meaning structures and systems of regulation and makes itself noticeable, for instance as something improbable or unharmonious. ${ }^{33}$ The process of gaining attention is not at all similar to a peaceful river: there are currents and whirlpools of varying intensity, with the »suddenness of the shock « at one end of the scale, and the »slumber of habit« at the other. ${ }^{34}$

\section{Phenomena of Visual Attention}

What, then, is the specific quality of visual experience, what allows a picture to become so strong in a phenomenological sense that it offends or attracts? In his 
phenomenology of visual attention, Waldenfels makes a distinction between "an effect of images « from a form of media, and »an effect that emerges through the images." The effect-producing image is to be differentiated from the effect it produces, just as a difference exists between a representation and the thing represented. It is a matter of the effect of an image as image, which does not follow the perception of the picture, but rather »rumbles within it, as an ongoing agitation. ${ }^{35}$ In this sense, the source of the effect is neither a visible nor a visual thing, but rather something without meaning or law, in a strict sense even non-visual. The strongest experiences render us speechless and go beyond our capacity to comprehend them: they defy classification and visual elaboration. Waldenfels detects in the commandment »Thou sbalt not make unto thee any graven image, « which expresses the religiously motivated ban on pictures, a resistance that says: »Thou canst not make unto thee any graven image. «36

How, then, does an invisible pathos leap out, how does a non-visual effect enter the picture and stage itself? »We have always had images before us, those we see and those we create, framed and unframed. We only encounter the effects of the power of imagination in the images it generates in secret. The source of what so affects us would forever remain blind and dumb [...] if it weren't for what we respond to, which articulates itself in signs and images. «37 In this vein, the offending picture reacts to the individual's inner store of images that is activated by the external image: I notice the picture because it looks similar to other images familiar to me, yet is different. While the similarity is a reaction to the pre-existing attitude, the aberration stands out as an impetus. The picture looks other than expected.

The difference between the visual effect that seeing sets in motion and the overall form of the image in which it develops and solidifies also enters into the 
image. »[...] One must distinguish between the seeing image that looks back at us and the seen image that we, for our part, see. $\ll^{3}$ In accord ance with the various forms that an image can adopt, Waldenfels distinguishes between varying forms of pathos and affect that give rise to different responses. The point of departure of a visual dynamic is the disquieted gaze, which requires a »disruptive stranger:« »It is the disquietude that keeps the gap between the seeing and seen image open [...], a mixture of attraction and repulsion that Kant ascribed to the sublime. $\ll^{39}$ Waldenfels locates this »disquietude « in the basic elements of art's »classic picture « and finds examples in the paintings of Malevich and Goya. It is these qualities of line, color, figure, and ground that »capture the viewer's gaze with a movement of the gaze that he has no control over. $\ll^{4^{\circ}}$ The pathos of the image, then, is greatest »when it is realized in a visual event that is physical, that generates space, « for instance in the greens and blues of Monet's Water Lilies. ${ }^{41}$

\section{Phenomena of Taking Notice}

Let us leave behind the historical aesthetic of the classical art picture of the Monet variety and regard a painting by a contemporary artist who has titled his work The Holy Virgin Mary (Fig. I). We are in the art museum now, in a special place for »creating attention:« art shifts the gaze from what the picture depicts to how it does this, thus shifting the viewer's focus to the act of attention and perception. Chris Ofili's The Holy Virgin Mary is a good example of this kind of attention. The painting shows what it shows not merely in a sur- 


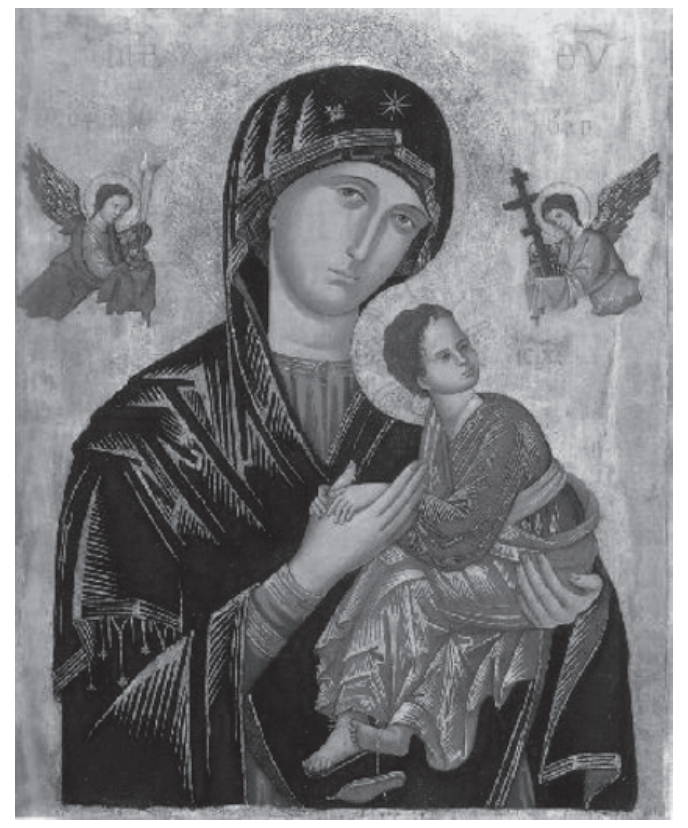

[FIG. 7]

Unknown artist: Our Lady of Perpetual Help, Byzantine icon, $15^{\text {th }}$ century, Rome, Esqueline Hill

prising, remarkable form - the Western history of pictures used a different form for the Holy Virgin Mary and the surrounding cherubs and anchored this pictorial form in tradition (Fig. I and 7).

The artist frames a reference to this iconic form by quoting the ornamental golden ground of Byzantine icons and medieval paintings of saints, which symbolizes an aura of holiness. At the same time, the dark skin and African features break with the traditionally Western canon of beauty, in which Mary's visage is portrayed as light-skinned and delicate. For those familiar with Madonna iconography, the dark skin of The Holy Virgin Mary refers back to the tradition 
of the »Black Madonna in the Song of Solomon (I.5): »Nigra sum sed Formosa.« The Holy Virgin Mary's nose and mouth do not, however, conform to the traditional topos of the »Black Madonna, « nor do they conform to other traditionally light-skinned Madonna pictures. The material of elephant dung, shaped into a cylinder and applied to the Madonna's breast, also shifts the viewer's gaze to the nature of this visual detail. By employing the irony of altering traditional pictorial forms, an irony that has strongly characterized avant-garde art since the beginning of the $20^{\text {th }}$ century, Ofili's Madonna confirms Waldenfels's remark that »the fine arts have also always been art forms of attention that lend space to the inconspicuous. $\ll^{42}$ The scandal, however, lies outside the painting, in the two bottom clumps inscribed with the painting's title Holy Virgin. The iconoclash contained within Ofili's painting attracts attention because the subject of the painting collides with its composition, for instance the pictorial elements in butterfly form, which are photographs of female genitals. In the art picture, as we may conclude from Waldenfels's phenomenology of visual attention, the most effective visual forces are compressed - an »iconopathy that lends the official iconology an additional dimension of depth by always addressing images as event images or as excitation images as well. $\aleph^{43}$ Waldenfels points out that »the history of viewing and fabricating pictures suffers from a self-made image oblivion. [...] The source of what affects us and what the responsive gaze reacts to becomes detached from what is seen in the image. [...] Seeing approaches recognition, for which everything is as clear as day and solidifies into a having seen. ${ }^{44}$ The result is that the picture is drained of its sensuousness, the origin of which process Waldenfels locates in Plato's picture theory. Plato sublimated the desire to see, the pathos and the visual magic that 
occur in the act of seeing, into a seeing with the mind's eye: »Ideas are the true images.

Waldenfels ascribes a potency sui generis to art, an ability to attract attention that does not stand in the service of non-art goals, for instance the creation of political consensus, the awakening of religious faith, advertising, or entertainment. Art pursues an »indirect mechanism of action« that derives from »a surplus in the extraordinary and aberrations from the orderly. «45 By heightening the form of attention, it has the ability to distort natural experience by redirecting the gaze from what it depicts to how it presents itself, drawing the viewer's attention to the process of attention and perception.

Ofili's painting and Neuwirth's fictional Conchita Wurst persona are two very different attention-getting visual phenomena (Fig. I and 5). Both bear features of something contrary, undesired, and injurious in that they refer to the customary and traditional in a manner that goes against the rules; this is why they are able to elicit emotional reactions such as astonishment, fear, repulsion, and even shock. In the case of Conchita Wurst, the aspect of the picture that induces shock is quickly identified: a bearded woman in a glamorous costume, reminiscent of a Christ icon. The outstanding feature here, as Waldenfels would also find, is outdone by the all-too-outstanding, while the event of seeing the picture is elevated to its content, an image event [Bildereignis] that keeps the picture machinery going, in this case that of the television-broadcast ESC. ${ }^{46}$ The figure's aim of attracting attention to a socio-political agenda, according to Waldenfels, also excludes the figure from the art context. In the case of Ofili's Holy Virgin Mary, the question as to the causes of the offensive effect is more complicated. The art context determines the pre-existing attitude 
according to which, in the late $20^{\text {th }}$ century, a painting that depicts a deformed female figure could hardly cause shock anymore. Here, it is the golden ground painted after the medieval tradition of pictures of saints, together with the flesh-colored »bubbles, " that draw attention, disquiet the eye, and can be perceived as »disruptive strangers.« The painting's title, hidden on the two supporting dung clumps, abruptly reveals the intention of an iconoclash directed particularly at Western viewers familiar with the tradition of Madonna portrayals. The painting's title pulls the work out of an art context and places it in a sacrosanct, religious tradition, which it breaks with in a provocative way through deformation. With its dogma of the greatest possible degree of freedom and autonomy, the contemporary art context is unable to protect the painting from the allegation of offensiveness. As a result, the iconoclash takes place in an in-between space produced by the painting, in which similarity and difference, tradition and innovation, Church and art battle one another.

Let us examine a third example: a large-format billboard of a pair of hands poised in diamond formation (Fig. 8). A closer look reveals that the picture is comprised of countless small photographs pieced together in the form of a mosaic. The hands on the billboard belong to the current German Chancellor, Angela Merkel. The billboard was part of her Christian Democratic Party's campaign for Germany's parliamentary election on September 22, 2013. With its huge horizontal format of $70 \times 20$ meters, the ad surprised both Berliners and tourists who happened to be near the Hauptbahnhof, Berlin's main train station. Press reports revealed it was comprised of 2,I5o photographs of Merkel supporters. The CDU's campaign slogan, printed on a second large-format billboard, read: 


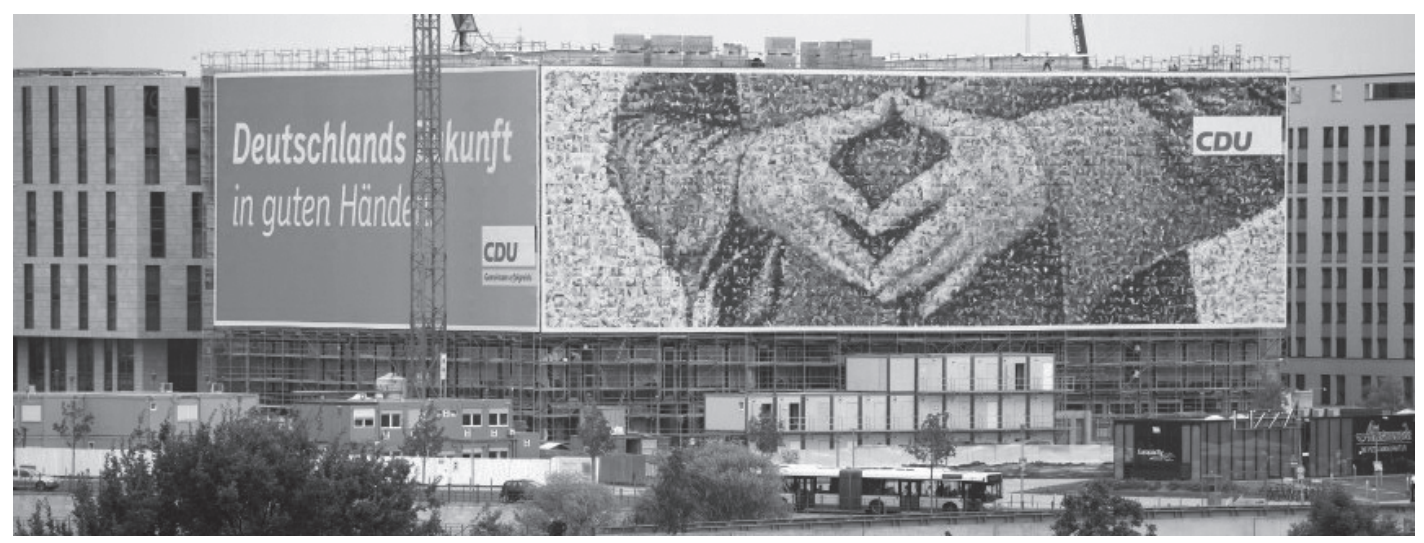

[FIG. 8]

Blumberry GmbH: Germany's Future in Good Hands (Deutschlands Zukunft in guten Händen), CDU campaign ad, Berlin, 2013

»Germany's Future in Good Hands. CDU.«In the race for the chancellery, the billboard's impact was that of a visual bomb followed by a tidal wave of commentary in the daily papers. The Berlin Social Democratic party chair complained about the »monstrous, hollow personality cult. [...] The poised fingertips signalize just how secretively the people of the three-party coalition behave toward one another « (he was referring here to the grand coalition of the CDU, the SPD, and the FDP, the business-friendly Free Democratic Party). ${ }^{47}$ Other commentators countered: »sacred allegations of this kind do not apply to the sober pastor's daughter.«Others considered it a highly symbolic gesture that signified the following: »The mother of the nation takes Germany by the hand and leads it out of the crisis.« The gesture, called the »Merkel rhombus« or »Merkelizer, « 
had already inspired numerous interpretations in 2009 , when the chancellor used it during her public speeches. ${ }^{48}$ Soon there was talk of »Mommy's hands, " which were characterized either as »old-motherly pastoral« or as »magical/ dangerous, " as the British magazine The Economist called them in an allusion to Tolkien's Lord of the Rings: »One ring to rule them all.«49 There was and is a broad consensus about the meditative nature of the hand gesture poised mid-body, refraining from action: it expresses concentration, prudence, and a search for points of connection. ${ }^{50}$ In a formal sense, the billboard distills the meanings ascribed to the hand gesture into an icon. Together, the large format and close crop of the picture, which reduces the chancellor to her hands, intensify the gesture's effect. Apart from the religious connotations and mystifying semantics the Merkel hands were alleged to carry, the billboard provided an occasion to debate the acceptability of huge election billboards in public space. In public opinion, the billboard debate, which took place prior to the election, oscillated between disparagement (there was no political content conveyed in the ad) and an appreciation of the picture as a »courageous art installation « with a highly symbolic statement. ${ }^{51}$ Someone even proposed that $\gg$ the billboard should remain in place, and a cathedral be built around it. « ${ }^{52}$

The team of Lutz Meyer, head of the Berlin advertising agency Blumberry and a political scientist, succeeded in creating a "powerful« picture for two reasons. Initially, among the gestures of political power, which are primarily male, the Merkel rhombus is a novelty: men tend to make a fist, stick out their hands, or raise an index finger. In the magazine section of the Süddeutsche Zeitung, the chancellor's contender, Peer Steinbrück, countered it with an equally powerful pic- 


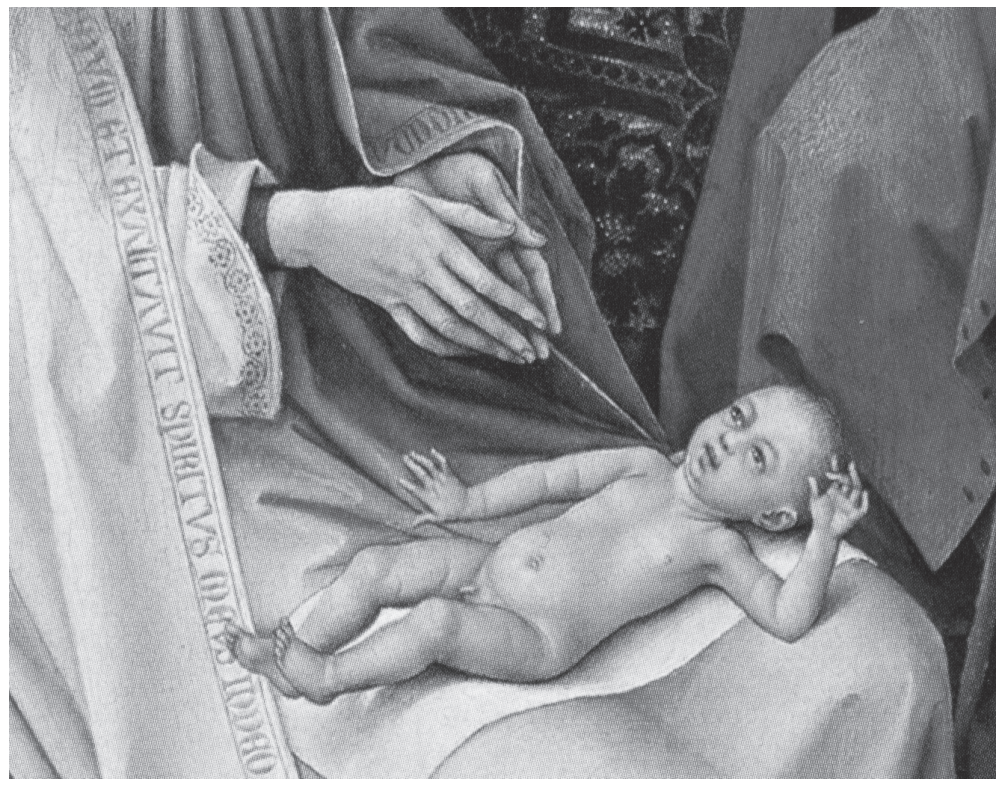

[FIG. 9]

Rogier van der Weyden: Bladelin Altarpiece, (Praying Hands of Our Lady), Berlin, Staatliche Museen, Gemäldegalerie

ture, the »finger. ${ }^{53}$ The iconization of the hand gesture Merkel chose is powerful because it carries meaning both in terms of iconography and the history of visual culture. ${ }^{54}$ In many cultures, it is used as a gesture of meditation or of religious contemplation in prayer. Iconographically, the iconic distillation of the gesture in the billboard leads to the Christian tradition of devotional pictures. One critic's comment that the billboard resembled an »antique painting with a cracked surface « points in this direction. 5 A short distance from Berlin's main train station, the Gemäldegalerie of the Berlin Kulturforum has fitting iconographic models for the Merkel rhombus in its collection of Old Masters, for instance late medieval paintings of Mary's adoration of the newborn Jesus (Fig. 9). 
The billboard icon, the debates over it, and the sacred interpretation of the Merkel rhombus compare Merkel's hands to the late medieval devotional picture, forming a connection between Mary and the »mother of the nation. « Whether or not the iconically distilled Merkel rhombus in the campaign billboard deliberately refers to late medieval painting is irrelevant. Using a prayer gesture in a political race, which the billboard both shows and conceals, makes the picture offensive to its critics. In a society based on a neutral worldview that nonetheless has to deal with religious fundamentalists who create political crises, the billboard, which subliminally communicates a confluence of politics and religion, holds a high potential for iconoclash. Here, too, the picture generates an interstice in which a traditional form undergoes a change in interpretation. In response to the billboard, and for varying reasons, traditionalists, religious communities, politicians, and the lay public could accuse one another of abusing a traditional form.

\section{Powerful Pictures of Hermeneutics}

Common to all three examples is that the more or less openly evidenced recourse to Christian pictorial tradition and a crossing over into a new functional space that stand in historical or current competition with this tradition becomes an occasion for offense. These pictures set themselves apart from the flood of imagery because they evoke this tradition in a place that is felt to be inappropriate. In the following case for a visual hermeneutics, this recourse to pictorial tradition is a reason behind the picture's strong effect, as well as for its »powerful being « and meaning. In his essay Zuwachs an Sein. Hermeneutische Reflexion und bildende Kunst (1996) 
[Increase in being. Hermeneutic reflection and the visual arts], the art historian and philosopher Gottfried Boehm, in a reference to Hans-Georg Gadamer, determines that »the picture's own being, which only attains power and becomes a powerful picture when reality transfers itself over to it, becomes iconically compressed. Powerful pictures are those that metabolize reality. They do not depict reality, but also do not oppose it, producing instead a dense unity that cannot be pried apart. $\aleph^{56}$ This is expanded by the following explanation, in which the phenomenological criteria quoted above are augmented by the hermeneutic argumentation:

»These kinds of pictures are powerful because they make a part of reality visible to us that we would never experience without them. The picture refers to itself (underscores itself, rather than cancels itself out), while at the same time it points to the subject represented. Thus, it is able to make a heightened truth visible, which raises it far above the mere presence that representations convey. « $\$ 7$ Where does the power come from that the powerful picture wields, how does the truth arise that it makes visible? The picture, according to Boehm in a reference to Gadamer, »becomes a part of the being of the subject represented. This is why every powerful picture is an occurrence of being that helps determine the level of being of the subject represented.« Furthermore: »through the representation, the subject represented undergoes an increase in being. $\left(\mathrm{WM}\right.$, p. I45). ${ }^{58}$ Boehm calls this »iconic difference. $\ll^{59}$ In its representation of everyday things, the painted still life, for instance, creates an enchanting world and lends things a »heightened truth of being. ${ }^{60}$ The religious picture, however, succeeds even more in bestowing an increase in being on the subject represented: »One may generalize that religious works are never satis- 
fied with merely depicting their powers. « ${ }^{6}$ The pictorial form of the vera icon demonstrates this in a special way: with the imprint, considered genuine, of Christ's facial features on a linen cloth, his true image translates the theological notion of real presence into a legendary picture.

The »increase in being, « the picture's power and truth, can be explained by this conflation of original image and likeness. From a hermeneutic perspective, the picture derives its power from the participation of the subject represented. For this reason, it can happen that a contemporary artist's Madonna portray$\mathrm{al}$ is not perceived as a work of modern art, but as a picture of a saint; in this way, the picture of a pop star can become a Christ icon and the billboard of a female hand gesture can be compared to devotional pictures. Boehm's visual hermeneutics, based on Gadamer, understand the pictorial artifact as an occurrence of being and grasps the picture as a »source of power, «a »process in the world. «According to Boehm, what is essential is the »spawning, « the »discovering, « the »sensuous power, « and the »spiritual energy of pictures « that connect to the »living reality. ${ }^{62}$ When these attributes exert their effect in the picture, visual hermeneutics refers to this as "powerful.«

\section{Splitting the Visual Order}

Boehm leaves no doubt that he wants the description "powerful« to be ascribed exclusively to works of art and architecture. For this reason, he draws a clear boundary between powerful pictures of art history and the ones he characterizes as »weak, « the mass media pictures that are machine-made, generated through 
technology. Their »aim and function consist in depiction, in disseminating information through the eye. [...] The logic of these pictures consists in self-abnegation, in the quest to [...] assume a posture of objectivity generally accepted to be the only source of appropriate and correct information. ${ }^{63}$ Like Waldenfels, Boehm spoke of the danger of decadence when he divided visual cultures into strong and weak in 1996, a decadence caused by the new media and technology of image transmission. The art historian located the »weakness « of an emergent visual culture of the masses in the intention of these pictures »to bring no will of their own into play, not to refer to themselves at all, but to approach the matter in an entirely transparent manner. [...] Consequently, these kinds of technical pictures are very weak pictures. « ${ }^{64}$ Boehm calls these weak pictures »copies, « and in doing so he verbalizes what Waldenfels called a »desensualization of the picture and, even more clearly and with reference to digital imagery, what Byung-Chul Han called an "affectum « that brings about an immediate satisfaction in response to a stimulus. ${ }^{65}$

According to Boehm, the mechanization of picture production that began with the invention of photography in the $19^{\text {th }}$ century was the key to its success, whereas the products of these picture machines are no more than »doublings, a double of reality. ${ }^{66}$ With the »rapid success of the weak everyday pictures, « the number of their authors also increases. ${ }^{67}$ In the mid-1990s, however, it was difficult to predict how many picture producers would be in a position, with the help of digital technology, to produce inconceivable numbers of new pictures every day. Boehm considered the family photo album, which was still popular at the time, to be the pinnacle of trivial, mass-media-produced »weak « pictures, which he compared to the »old world « of art. The »readily comprehensible economy of 
pictures [the reference here is to art, C.K.] that is cultivated in designated places, on chosen occasions, and in keeping with the legitimacy of its content, lies like a distant continent on the horizon of the past. ${ }^{68}$

In this vein, the traditional, elitist visual orders of art history give way to the disorder of the non-art pictures that the new mass media produce without respite in order to »smuggle in « reality as a reservoir of information in »society's circulation of information. «99 As stated above, Boehm was unable to predict in 1996 what elements of visual culture would undergo profound change in the coming years - but he already suspected how much potential the new picture machines had for the »old world, with its rich, but readily comprehensible economy of pictures.« The reference here is to art's »powerful« pictures, on which he bases a strong concept of modern art. $^{70}$

\section{What Makes Pictures Powerful}

Let us return to our very different examples and the question of what makes them so powerful that they are able to attract attention, emerge from the flood of pictures, and inspire offense or produce an iconoclash (Fig. I, 5, 9). I chose the examples from three contexts of contemporary visual culture, all of which are very different from one another, but have something in common. Each is connected to the pictorial forms, types, and traditions of the old world of Catholic Christianity: the Madonna icon, the Christ icon, and the devotional picture. In the examples, these old pictorial forms appear in contemporary form and as such prove to be effective pictures of young art, a pop star, and an election campaign billboard. 
The Western world pays special attention to the pictures of saints preserved in churches and museums, one visited by devout Catholics and the other by art experts and lovers. In the »old [Christian] world, «for those who believed in them, they still possessed the »strong sense of the iconic« that induced the divine being »to meaningfully, visually appear« in that »the intrinsic iconic value has an effect on the original archetype. $\ll^{71}$ According to this, hermeneutic criteria for the »strongest « picture are to be found in the pictures of saints and rulers: God and rulers »essentially have their being in the act of showing themselves (WM, p. I47). " $^{2}$ In the »old world « of art, this hermeneutic pictorial quality was preserved in museums as a memento. In contemporary picture cultures, this old, culturally practiced participation of pictures in the sovereign and divine perpetuates their effect in a paradoxical way. We don't know whether Rudolph Giuliani prays before a painting of the Madonna in his parish church. In any case, however, he sees Mary's image desecrated in Ofili's painting. For anyone who, while not believing in the pictures of saints, still defends the Church institutions connected to them, the three contemporary examples embody the divine that appears as a pictorial tradition in their updated forms, just as much in the costumed Conchita Wurst as in Chancellor Merkel's election campaign ad. These visual effects are paradoxical because, for the faithful, the old, powerful Christian pictures are the triggers of an iconoclash.

Removed from their sacred or museum context, these pictures of the old world exert their effect in the profane space of a Western world that presents itself as secularized, especially here. They transfer their former power to their updated artistic or mass-media versions through a contemporary guise. They are offensive to those who see their original models caricatured, defamed, or misused. On the other hand, they are welcomed by those who are reminded of the 
meaning of the old devotional pictures and who lament their deformation through institutions and potentates. While some are outraged over the distortion, others attest to the traditional values of the Christian mission that they communicate. In both cases, they confirm the thesis of hermeneutics, which asserts that the object represented participates in the being of the representation; conversely, they refute the thesis of the »weak « mass-media pictures.

The visual qualities of Conchita Wurst that have nothing to do with art, such as the extreme degree of conspicuousness and the entertainment purpose, collide in the Christ-like transvestite look of a pop star with a hermeneutic pictorial meaning that never would have been unleashed without this picture. Conchita Wurst therefore uses the »powerful Christian image form to attract attention and, through this, to set in motion a discourse, not about Christ icons, but about social issues of contention, for instance homosexuality and Christian values of tolerance.

The CDU's campaign ad aims for an iconization of an ambivalent gesture; indirectly and rich in allusion, it employs a gesture conveyed through previous imagery in order to communicate, together with its claim, trust in the values connected to the $\mathrm{C} \ll$ in $\mathrm{CDU}$. The power of this picture-text message provoked the iconoclash its political opponents brought about, whose ironic and polemical rhetoric amounted to little more than a weakening of the Christian connotations in the meaning of picture and text.

The three examples have shown that the »old « hermeneutic quality of the »power of the image « regarding today's visual cultures allows for no division of the world into old, powerful (art) pictures and new, weak media pictures. The two worlds have long since merged: media pictures with art and traditional 
imagery, and art with media pictures. And the phenomenological Wirkmacht und Wirkkraft der Bilder (Power and Potency of Images) shows a permeability in both directions in terms of a clear differentiation between the effects produced by art and by non-art. Or, as Gottfried Boehm remarked with an eye to the art of the late $20^{\text {th }}$ century: »The spectrum of modern art experience is broad and contains examples of subtle spirituality as well as instinctive vitality, inscrutable profundity, and blatant banality.«73 Not least, the three examples serve as reminders that even in modern Western societies, which have tended to profile themselves as secular since the Enlightenment, pictures as vehicles of symbolic form have not stopped conveying the canon of Christian ethical values.

1 *I am grateful for intense discussions with Birgit Meyer, who accompanied the progress of this paper and encouraged me to study religious artworks in contemporary visual cultures. With Jojada Verrips I could discuss an earlier version of this paper. In this paper I am dealing with pictures, using the English term to stress the interplay of image and medium following Hans Belting: An Anthropology of Images. Picture, Medium, Body, Princeton 20II, p. I-36, here p. Io-II: »The picture is the image with a medium. [...] The picture calls [...] for a new discussion with reference to its place within the history of pictorial media. But it also requires a spectator who is able to animate the media as though images were living things. Image perception, a form of animation, is a symbolic act that is guided by cultural patterns and pictorial technologies.«

2 Cf. the chapter Offending Images in William J. T. Mitchell: What Do Pictures Want? The Lives and Loves of Images, Chicago and London 2005, Pp. III-124, here p. 126. Mitchell gives the following definitions: »By >image $<$ I mean any likeness, figure, motif, or form that appears in some medium or other. By >object $<$ I mean the material support in or on which an image appears, or the material thing that an image refers to or brings into view. [...] By >medium $<$ I mean the set of material practices that brings an image together with an object to produce a picture.«Ibid., pp. XIII.

3 Ibid., Pp. I3 ${ }^{\mathrm{I}-1} 3^{2}$.

4 The exhibition Sensation, with works by Young British Artists from the Saatchi Collection, opened in 1997 in the Royal Academy of Arts in London, made a stopover in Berlin, and finally traveled to New York's Brooklyn Museum, where Chris Ofili's The Holy Virgin Mary provoked prominent visitors, including New York's mayor at the time, Rudolph Giuliani, as well as the less prominent visitor Dennis Heiner, who »piously« covered the work in white paint. 
5 Cf. David R. Roediger: Colored White. Transcending the Racial Past, University of California Press 2002, pp. 35-39. Roediger explains the political and racist context of the attack on Ofili's painting with Giuliani's origins in an ItalianAmerican immigrant family.

6 Mitchell: What Do Pictures Want? (see note 2), pp. 135-136.

7 For more on Guiliani's religious and political predispositions, see Roediger: Colored White (see note 5), pp. 33-35.

8 »The interplay between image and technology, old and new, constitutes a symbolic act. The response, the audience's perception of the image, is also a symbolic act. Hans Belting: An Anthropology of Images (see note I), p. Is.

9 See ibid., pp. 9-12., in the introduction »Picture, Medium, Body.«

${ }^{10}$ Mitchell: What Do Pictures Want? (see note 2), p. XIV.

11 Birgit Meyer uses the term »sensational form « to convey the complex interplay between producing, mediating, and receiving bodies during the genesis of an extraordinary presence, for instance the divine. »Playing a key role in implementing a particular religious aesthetics through a process of religious socialization that occurs over time, sensational forms include body techniques as well as sensibilities and emotions that become embodied dispositions in the habitus.« Birgit Meyer: Picturing the Invisible, in Aaron W. Hughes / Steven Ramey (eds.): Visual Culture and the Study of Religion, 27/4-5 (2015), pp. 333-360; see also Birgit Meyer: Mediation and the Genesis of Presence. Towards a Material Approach to Religion, Utrecht 20I2, pp. 26-3I.

12 Bruno Latour: What is an Iconoclash? Or is there a World Beyond Image Wars?, in Bruno Latour / Peter Weibel (eds.): Iconoclash, vol. I, ZKM Karlsruhe and MIT Cambridge,
Mass. 2002, Pp. 14-37. Latour undertook a »basic classification of iconoclastic gestures, « which I will come back to.

13 Ibid., p. I8.

14 Ibid., p. 24.

15 Roediger: Colored White (see note 5), expounds upon the breach in art's autonomy in the case of The Holy Virgin Mary.

16 Gerrit Bartels, in Der Tagesspiegel, No. 22042, (May I2, 2014), p. 19.

17 Der Tagesspiegel, No. 22043, (May 13, 2014), p. 24

18 Quote from the online issue of the Kronenzeitung, May I6, 2014, http://www.krone.at/Oesterreich/Kardinal_ Schoenborn_ueber_Conchita_Bete_fuer_ihn-Offene_ Worte-Story-40460I (accessed on Sept. 8, 2015).

19 See note II.

${ }^{20}$ Quote from the online issue of http://kurier.at/menschen/ im-gespraech/conchita-wurst-ein-bart-alleine-reichtnicht/27.066.462 (accessed on Sept. II, 20I5)

${ }^{21}$ Neuwirth in an interview with Die Welt prior to the ESC on May 6, 20I4. http://www.welt.de/vermischtes/prominente/ articler27667355/Aussehen-und-Geschlecht-sind-voelligWURST.html (accessed on Oct. 9, 2015).

${ }^{22}$ When not otherwise indicated, German quotes not available in English-language editions have been freely rendered into English (A.S.). »Sonderform sui generis.« See the following quotes in Lambert Wiesing: Die Sichtbarkeit des Bildes. Geschichte und Perspektiven der formalen Ästhetik, Reinbek near Hamburg 1997, Pp. 160-164, here 161. The English translation by Nancy Ann Roth, published by Blooms- 
bury/London in September 2016, was not yet available to the author (C.K.).

23

"Jedes Bild muß seine Oberfläche zu einem eigenständigen Phänomen erheben, das heißt eine Differenz zwischen der Bildoberfläche und dem Bildmaterial aufbauen.«Ibid.

${ }^{24}$ This didn't seem to bother Giuliani; in any case, it is not mentioned here. See the discussion in Roediger: Colored White (see note 5), Chapter 2.

${ }^{25}$ See ibid., pp. 35-36 for a tradition, not always welcomed by the Church, of black Madonnas in southern Italy.

26 »[...] was ein formales Bildverständnis unter künstlerischen Wahrheitsansprüchen versteht [...].« Wiesing: Die Sichtbarkeit des Bildes (see note 22), pp. 193-204, here p. 193.

27 »[Das Bild, C.K.] Die Kunst erscheint als ein Angriff auf den Zustand des Betrachters: denn dieser muß verändert werden, soll er die Welt so sehen, wie sie dargestellt ist.«Ibid., p. 203.

${ }^{28}$ „Es reicht für Kunstwerke nicht aus, die Welt in einer Weise darzustellen, sondern darüberhinaus muß diese Sichtweise den Betrachter veranlassen, selbst die Welt in einer veränderten - möglichst mit der im geplanten Sinn veränderten - Sicht zu sehen. [...] Mit der Formulierung ,Wahrheit [des Bildes, C.K.] der Kunst kann man das Funktionieren einer Welterschließung beschreiben, also die Fähigkeit des Bildes [Werkes], die Wirklichkeit in einer Weise darzustellen und zu interpretieren, die auch für andere eine Weise sein kann.« Ibid.

29 »Wir haben es mit einem Doppelereignis zu tun: etwas fällt mir auf - ich merke auf.« For the following, see Bernhard Waldenfels: Sinne und Künste im Wechselspiel. Modi ästhetischer Erfahrung, Chapter 4: Wirkmacht und Wirkkraft der Bilder, Frankfurt on the Main 20I0, pp. I05-I32, here p. IIo.
30 "Was uns auffällt und überrascht, kommt stets zu früh, während unsere Antwort stets zu spät kommt [...].«Ibid., p. II2.

31 »[... die Ereignisse des Auffallens sich in wiederholbaren Qualitäten sedimentieren und die Ereignisse des Aufmerkens sich körperlich habitualisieren.«Ibid., p. II5.

32 "[... zur Ausbildung bevorzugter Merkwelten, in denen sich kollektive und individuelle Interessen spiegeln.« Ibid., pp. II5-II6.

33 Ibid., p. II6.

34 „An dem einen Ende der Skala finden wir die Plötzlichkeit des Schocks, [...], an dem anderen Ende den Schlummer der Gewohnheit.«Ibid., p.II6.

$35 »$ Die Bildwirkung tritt nicht neben die Bildwahrnehmung, $[\ldots]$, vielmehr rumort sie in ihr all seine permanente Beunruhigung.«Ibid., p. I20.

${ }^{36}$ Ibid., p. 120.

37 „Wir haben immer schon Bilder vor uns, gesehene und geschaffene, offene und gerahmte. Das Wirken der Einbildungskraft begegnet uns einzig in jenen Bildern, die sie im verborgenen erzeugt. Das Wovon des Getroffenseins bliebe auf ewig stumm und blind [...], wenn es nicht das Worauf des Antwortens gäbe, das sich in Zeichen und Bilden artikuliert [...].«Ibid., p. I21.

38 „[...] zu unterscheiden [ist] zwischen dem sehenden Bild, das uns anblickt, und dem gesehenen Bild, das wir unsererseits sehen.«Ibid.

39 »[...] es bedarf jener >störenden Fremdlinge< [...]. Es ist die Unruhe, die den Spalt zwischen sehendem und gesehenen Bild offenhält. Dau gehört jene aus Attraktion und Repul- 
sion gemischte Bewegung, die Kant dem Erhabenen vorbehält [...].«Ibid., p. I23.

40

"Auf solche Weise wird der Betrachter von einer Blickbewegung erfasst, die er nicht beherrscht.«Ibid., p. 124.

41 Ibid., p. 125.

42 »Bildende Künste stets auch Aufmerksamkeitskünste sind, die dem Unauffälligen Raum geben.«Ibid., p. I28.

43 „Doch eine Ikonopathie, die der eingebürgerten Ikonologie eine zusätzliche Tiefendimension verleiht, [...], müßte noch elementrarer ansetzen, indem sie Bilder stets auch als Ereignisbilder oder als Erregungsbilder thematisiert.« Ibid., p. 123 .

44 »Die Geschichte der Bildbetrachtung und Bildverfertigung leidet unter einer hauseigenen Bildvergessenheit. [...] Dies rührt daher, daß die Schwelle, die das Wovon des Getroffenseins und das Worauf unserer Blickantwort von dem abgesondert wird, was wir jeweils im Bilde sehen, abgesenkt wird. [...] Das Sehen nähert sich dem Wiedersehen, für das alles sonnenklar ist, es verfestigt sich zum Gesehenhaben.«Ibid., p. I25.

45 »Indirekte Wirkungen gehen zurück auf Überschüsse des Außerordentlichen und auf Abweichungen vom Ordentlichen.«Ibid., p. 128 .

${ }^{46}$ Ibid., p. I27; see also Byung-Chul Han: Die Errettung des Schönen, Frankfurt on the Main 2015, one of many apologists to lament the loss of sensuality, for instance in an aesthetic of slick surfaces in which the viewer merely encounters his or her own reflection.

47 http://www.tagesspiegel.de/berlin/die-merkel-raute-wassagen-uns-diese-haende/8735882.html (accessed on Sept. I4,
$2015)$

${ }^{48}$ Helmut Kohl was the »father of the rhombus, « as a 1996 photograph by Konrad R. Müller of the then-chancellor with President Bill Clinton in Milwaukee shows; see http://www. tagesspiegel.de/politik/historische-aufnahme-helmut-kohlder-vater-der-raute/133107I2.html (accessed on Mar. I8, 2016).

${ }^{49}$ http://www.welt.de/politik/wahl/bundestagswahl/articleı19966030/Britisches-Magazin-empfiehlt-WiederwahlMerkels.html (accessed on Sept. I4, 2015).

${ }^{50}$ http://www.spiegel.de/kultur/gesellschaft/silke-burmesterueber-die-merkel-raute-a-922088.html (accessed on Sept. I4, $2015)$.

${ }^{51}$ http://www.art-magazin.de/div/heftar chiv/20I4/3/II9I84548 63120397786/Was-die-Raute-bedeutet (accessed on Sept. I4, 2015).

${ }^{52}$ http://www.dw.com/de/wahlkampf-mit-der-merkelraute/a-17067023 (accessed on Sept. 14, 2015).

53 Süddeutsche Zeitung Magazin, Sept. I2, 2009

${ }^{54}$ Merkel's own motivation for her rhombus-shaped hand pose is that it serves as an ergotherapeutic »aid for upright posture « and offers an aesthetic »sense of symmetry.« http:// www.dw.com/de/die-kanzlerin-erkl\%C $3 \% \mathrm{~A}_{4}$ rt-die-merkelraute/av-16786696 (accessed on Sept. I4, 2015).

55 Jens Thurau: Wahlkampf mit der »Merkel Raute«, http:// www.dw.com/de/wahlka mpf-mit-der-merkel-raute/ a-17067023 (accessed on Sept. 14, 2015).

56 »Aber auch eigene >Sein des Bildes<(WM, p. I44f.) gewinnt nur Macht, wird zu einem starken Bild, wenn sich in ihm >Realität< übereignet, ikonisch verdichtet. Stark sind solche 
Bilder, die Stoffwechsel mit der Wirklichkeit betreiben. Sie bilden nicht ab, sie setzten aber auch nicht dagegen, sondern bringen eine dichte, >nicht unterscheidbare Einheit< zustande.« Reprinted in Gottfried Boehm: Wie Bilder Sinn erzeugen. Die Macht des Zeigens, Berlin 2007, pp. 243-267.

57 »Stark sind solche Bilder, weil sie uns an der Wirklichkeit etwas sichtbar machen, das wir ohne sie nie erführen. Das Bild verweist auf sich selbst (betont sich, anstelle sich aufzuheben), weist damit aber zugleich und in einem auf das Dargestellte. So vermag es eine gesteigerte Wahrheit sichtbar zu machen, die es über die bloße Vorhandenheit, welchen Abbildung vermitteln, weit hinaushebt.«Ibid.

58 "Das Bild, [...], gehört zum Sein des Dargestellten hinzu. Deshalb ist jedes starke Bild ein Seinsvorgang, der den Seinsrang des Dargestellten mitbestimmt. Mehr noch: ,Durch die Darstellung erfährt es gleichsam einen Zuwachs an Sein (WM, p. 145).«Ibid., p. 254.

${ }^{59}$ Gottfried Boehm: Die Wiederkehr der Bilder, in G. Boehm (ed.): Was ist ein Bild?, Munich 1994, pp. II-38, here p. $29-36$.

60 "gesteigerte Wahrheit ihres Seins«; quote by Gadamer, Wahrheit und Methode (WM), pp. 142, 156, in Boehm: Wie Bilder Sinn erzeugen (see note 56), p. 255 .

61 »Religiöse Werke, so darf man verallgemeinern, begnügen sich niemals damit, ihre Mächte lediglich abzubilden.« Ibid., p. 256 .

62 Boehm formulates these criteria of the powerful image in light of abstract art. He stresses its »hervorbringende, « »entdeckende, «»sinnliche Kraft, « »geistige Energie der Bilder« that connect with »Lebenswirklichkeit; Ibid., p. 265.
${ }^{63}$ Its ZZiel und Funktion besteh[t] darin, abzuschildern, Informationen via Auge zu verbreiten. [...] Die Logik dieser Bilder besteht in einer Selbstverleugnung, im Bestreben [...], die Haltung einer Sachhaltigkeit einzunehmen, der man allein angemessene und richtige Information zutraut.«Ibid., pp. $246-247$.

64 „Es vollendet seine Intention dann am besten, wenn es keinerlei Eigenwillen ins Spiel bringt, gar nicht auf sich verweist, sondern sich ganz transparent macht auf die Sache. [...] Die so gearteten technischen Bilder sind mithin ganz schwache Bilder.«Ibid., p. 247.

${ }^{65}$ Bernhard Waldenfels: Wirkmacht und Wirkkraft der Bilder, p. I25; Buyung-Chul Han: Die Errettung des Schönen, Frankfurt on the Main 2015, Pp. 5-51.

66 „Verdoppelungen, ein Double der Realität»; Boehm: Wie Bilder Sinn erzeugen (see note 56), p. 248.

${ }^{67}$ Ibid., p. 247.

68 „Die alte Welt mit ihrer reichen, aber doch überschaubaren Ökonomie der Bilder, die an ausgezeichneten Orten, bei ausgewählten Gelegenheiten und nach der Legitimität ihrer Inhalte kultiviert wurde, liegt wie ein ferngerückter Kontinent am Horizont der Vergangenheit.«Ibid., p. 248.

69 „Wer Abbilder macht, der möchte sie mobilisieren, in den Informationskreislauf der Gesellschaft einschleusen.«Ibid., p. 248.

${ }^{70}$ For this reason, Wie Bilder Sinn erzengen is solely concerned with the old world and the powerful images of art.

71 »In der Repräsentation wirkt der ikonische Eigenwert auf das Urbild zurück. [...] >Das Bild ist ein Seinsvorgang - in ihm kommt Sein zur sinnvoll-sichtbaren Erscheinung [...] (WM, 
S. 194) « Ibid., p. 256-257.

72 »Der Herrscher hat sein Sein >wesenhaft im Sich-Zeigen (WM, S. I47).«Ibid., p. 257.

73 „Das Spektrum moderner Kunsterfahrung ist jedenfalls weit, enthält Exempel subtiler Spiritualität wie triebhafter Vitalität, abgründigen Tiefsinns und unverhohlener Banalität.« Here, however, the passage reads »Kunsterfahrung; «ibid., p. 263 